\title{
Style and Tradition in Karaikkudi Vina Playing
}

\section{Citation}

Wolf, Richard K. 1991. Style and tradition in Karaikkudi vina playing. Asian Theatre Journal 8(2): 118-141.

\section{Permanent link}

http://nrs.harvard.edu/urn-3:HUL.InstRepos:9894540

\section{Terms of Use}

This article was downloaded from Harvard University's DASH repository, and is made available under the terms and conditions applicable to Other Posted Material, as set forth at http:// nrs.harvard.edu/urn-3:HUL.InstRepos:dash.current.terms-of-use\#LAA

\section{Share Your Story}

The Harvard community has made this article openly available.

Please share how this access benefits you. Submit a story.

Accessibility 


\title{
Style and Tradition in Karaikkudi Vīna Playing
}

\author{
Richard Kent Wolf
}

Characterizing the "style" of a culture-the unique, special, or culturally marked aspects of social groups, their behavior, and their products-remains a central challenge for scholars writing about culture and the arts. (See, for example, Shapiro 1953; Gombrich 1968; Ackerman 1978; Kroeber [1957] 1973; Lang 1987; and Feld 1988.) Style is, for some scholars, an analytical abstraction defined by the observer to order and understand a given set of practices or objects-a view proposed quite explicitly, for example, by the art historian James Ackerman (1962; 1978, 158-159). But there is another notion of style-one defined and used strategically by participants. This alternative way of thinking about style is the focus of my discussion. ${ }^{1}$ After briefly contextualizing academic notions of style I will present a case study which illustrates notions of style held by performers of South Indian classical music.

Western intellectual discourses about style can be broadly divided into those concerned with the production of artifacts and those concerned with the character of entire cultural units such as ethnic groups or nations. In the former discourse, style comprises the characteristic and widely shared features of a particular set of artistic products or processes in such creative endeavors as music, painting, sculpture, literature, and architecture. ${ }^{2}$ It is usually discussed in relation to (rather than including) particular social and historical configurations. ${ }^{3}$

Historians and critics of art share this general notion of style but disagree on the best way to discuss it. As Walton ([1979] 1987) notes, for example, writers on style differ in their degree of emphasis on cultural

Richard Kent Wolf is a doctoral candidate at the University of Illinois at Urbana-Champaign, and is currently conducting field research in South India.

Asian Theatre Journai, Vol. 8, no. 2 (Fall 1991). (C) 1991 by University of Hawaii Press. All rights reserved. 
processes or products. But whether style is, as Kubler writes ([1962] 1976), a series of sequential changes with beginning, middle, and end, or as Ackerman claims (1962), a means of establishing relationships among works of art, or as Meyer argues ([1979] 1987; 1983), a replicative patterning resulting from a series of choices made within some set of constraints, stylistic categories are, for these historians at least, analytical tools used to order distinct elements or objects.

Anthropologists have also been interested in art styles. Franz Boas and his students (Boas [1927] 1955, 144-182; see Gerbrands 1969, 64) may have been the first to emphasize the effect of individual artists on group style, but like historians of the arts, none considered conceptions of group style from the perspective of the group itself. ${ }^{4}$ A notion of style more encompassing than that espoused by art historians gained currency from the 1920 s as anthropologists became interested in the features that unify a society. Certain "patterns," "themes," or "styles" were seen to underlie such domains as social structure, arts, agriculture, religion, and fashion. To these anthropologists, a cultural style was simply a characteristic way of doing something, evident in many sorts of cultural activities. ${ }^{5}$ The styles emerging from these studies turned out to be sets of predominant psychological dispositions - a logical, if reductive, way of explaining recurrent themes and structural isomorphisms (Kroeber [1957] $1973,73){ }^{6}$

The writers, observers, or scholars mentioned here-as well as others participating in the formation of both discourses-argue that style possesses unity, a cohesiveness comprising a "core" set of features isolated from a universe of possibilities. These features may be products or processes and may be viewed from a synchronic or diachronic, cultural or social, perspective. But for the most part, the shared features in this universe are privileged - that is, observers label those features important which seem to recur in several cultural domains and occur among the largest number of examples within a stylistic category. The reverse is true, as well, for categories are often constructed around shared features. Are shared features the ones most valued by the practitioners themselves? Or, for that matter, do practitioners even think in terms of shared characteristics?

Some performers in Asia, and probably others throughout the world, see themselves as belonging to social groups of performancesometimes translated as "styles" or "schools" in English. The defining features of these styles are constantly open to negotiation, and their members forever draw new boundaries and make new distinctions. Style as a social grouping (and not a normative category) in the performing arts in South India, and probably elsewhere, is usually a polythetic category (see Needham 1975) - that is, one which comprises characteristics that are not 
necessarily shared by all members. Given such fluid notions of style, "a style" is difficult to objectify in terms of a single collection of central features. Thus we must ask: How do performers think of style? How is change considered in light of stylistic notions?

Two performers of South Indian music, members of the Karaikkudi style of vinna playing, exemplify the preservation of their tradition in modern-day Madras. ${ }^{7}$ Both performers, Smt. Raajeswari Padmanabhan and Smt. Ranganayaki Rajagopalan, live and teach in Madras and have performed widely in India and internationally. Each performer is unequivocally regarded as a legitimate exponent of the Karaikkudi vinna style. Membership in a South Indian musical style entails indigenous conceptions of style in South India. Yet the two artists have interpreted their roles in maintaining their style in sharply contrasting ways. By elucidating the flexibility of the concept of style I hope to specify and contextualize factors that induce stylistic diversity.

Discussions of style, especially cross-culturally, can become almost trivial given the semantic range of the word "style" in English. Karaikkudi vinna $\bar{a}$ players use a number of terms in reference to their own tradition and relevant to their own understandings of the English word "style." Three of these terms, more or less glosses for "style" in certain contexts, provide a partial conception of what South Indian musicians mean by style and what English speakers might intuitively call style. The first, pāni, means "style," "manner," or "peculiarity" according to the Tamil Lexicon (University of Madras 1982). It is "the characteristic style of singing or performing associated with a particular singer or instrumentalist" according to the late $\mathbf{P}$. Sambamoorthy, an eminent Indian musicologist $(1952,39)$. The word is commonly used in naming a given style-for example, the Karaikkudi pāni Performers also use pāni to refer to aspects of tradition which extend beyond the music itself. For example, the late G. N. Balasubramanian interpreted pāni as "path" or mārga-a way, a proper course, or a "high" as opposed to vulgar style of performance (Monier-Williams [1899] 1979, 812). The late T. R. Mahalingam (1985, 39) saw the South Indian pạni as "that which reflects the soil of the south."

The second term, vali, is etymologically a Tamil word which means "manner, method, or mode" in the context of musical style. The broad definitions of the term, however, reveal deeper meanings. For example, vali can mean "a path," "a road," or "a way"; "a way in a moral sense"; and "antiquity or oldness" - all reflecting the traditional attitudes toward cultural institutions in India. A style of music is taught by one's guru; it is seen as a metaphorical "path" to the divine and as a way to fulfill one's dharma (right conduct) or "way" in a moral sense; moreover, a style is in many cases seen to be or claimed to be old. Vali is 
used in the same or similar contexts as panni-and Sambasiva Iyer once defined pāni in terms of vali $(1953,18)$-but the tradition is not, in my experience, referred to as the "Karaikkudi vali."

The third term related to style, palakkam, means "initiation, training, exercise, use" or "habit, practice, custom." My teacher, Karaikkudi Lakshmi Ammal, used this word to explain what was permissible in her vinna style. For example, she used to say that in her palakkam one does not allow the instrument to slide along the floor or to tilt back and forth while playing.

Each term reveals different aspects of style in South India: style is a way or manner in which something (in this case music) is carried out; adherence to it is considered of value; and learning it involves a particular kind of training and initiation. Applied to style in music, these terms can take on, but are certainly not limited to, purely technical meanings. In fact, the "old way" of transmitting knowledge from guru to sisya (disciple) precludes learning how to produce music from the vinna without being exposed to the master's own attitudes, quirks, and habits. As Daniel Neuman writes in The Life of Music in North India $(1980,50)$ :

The guru enculturates the shishya into musical life. He transmits two elements, neither of which is available through any other medium of instruction: a body of knowledge which is both secret and esoteric, and the way a musician must lead his life. This total musical life provides important evidence that social relations between musicians are indeed systematic. It comprehends a subculture in India which cuts across the boundaries of sex, religion, age, caste, territory, language, as well as time, yet includes all these as internal categorical distinctions.

Such aspects of the learning process do not find strong expression in an institutional setting for many reasons, the most obvious being that university students spend very limited time with their teachers.

\section{The Karaikkudi Brothers}

The Karaikkudi style is named for the town in which two brothers, Subbarama Iyer (1883-1936) and Sambasiva Iyer (1888-1958), rose to fame. Themselves seventh-generation vin̄a players whose forefathers had received princely patronage in the South Indian courts of Pudukottai and Sivaganga (Subramanian 1986), they were known for the brilliant tone of their instruments and for their stage presence. On stage they fulfilled complementary musical roles which were highlighted by the postures they assumed: the older brother held his vin $\bar{a}$ vertically and the younger held his horizontally. The older brother, Subbarama Iyer, was known for his 
exposition of niraval svara (melodic improvisation on a line of text within the structure of the $t a \bar{l} a$, or rhythmic cycle), for his kalpana svara (melodic and rhythmic improvisation using Indian solfege syllables), for his singing (while playing) of pallavi (a musical form which relies heavily on the exposition of kalpana and niraval svara), and for his extraordinary control over laya (tempo). Sambasiva Iyer was known for his refined technique and his exposition of tānam (elaboration of a răga, or musical mode, set to a nonmetric rhythmic pulse).

In a speech honoring Sambasiva Iyer at the Music Academy of Madras in 1952, his student and friend S. Sethuraman took the opportunity to reflect on the brothers' playing postures, comparing the "vertical" (ürdhva) position, somewhat noble or manly (purusa), to the god Siva and the horizontal, or "traditional" (sampradāya) position, possessing "gentleness" (sätvikam), to the goddess Śrī Śakti (Sethuraman 1952, 55). This contrast indicates that not only in the present but even when the brothers were performing together a certain degree of diversity characterized the style.

During the lives of the two brothers the Karaikkudi style involved, among other things, technical aspects as well as attitudes toward teaching and playing. Technical aspects included a distinctive method of fingering, ${ }^{8}$ a firm left-hand "grip" (aluttam) and controlled right-hand plucking motion (see Subramanian 1986, 182n.), a quality of kampiram (Meenakshi Ammal 1988) or weighty masculine touch (when women play with such a touch, they are sometimes described as playing like "gents"), and a stark

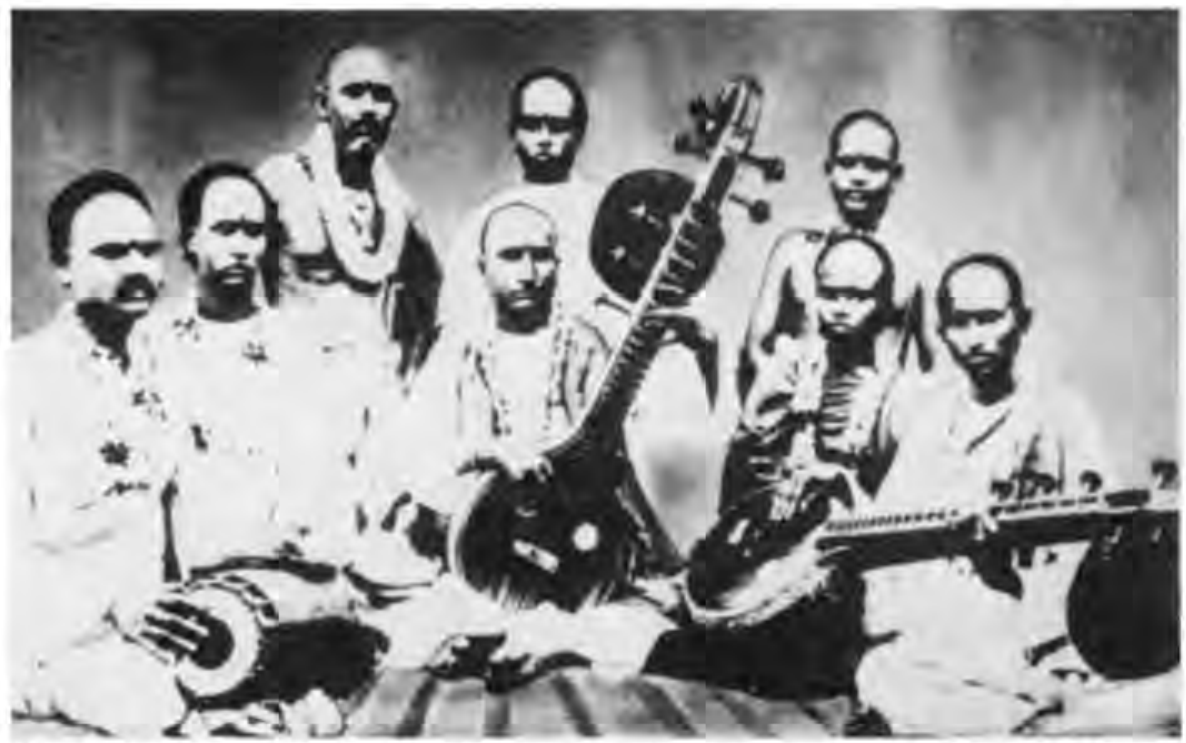

Figure 2. The three instrumentalists in the front row are Karaikkudi Sambasiva Iyer, Karaikkudi Subbarama Iyer, and Dakshiamurthy Pillai in a photo taken around 1928. (Photo: Richard Kent Wolf, courtesy of Subbarama Iyer's family.) 
and clear-cut mode of execution. The Karaikkudi teaching method consisted of specific exercises valued for themselves almost as ritual and emphasized mastery of the fundamentals at each level of instruction.

A similarly conservative conception of the musical repertoire is evident in a speech Sambasiva Iyer addressed to the Madras Music Academy in 1952, in which he expressed his belief that a musician should understand the meaning of the text used in performance and that the role of the musician is to interpret these texts musically-not to invent new ones (Sambasiva Iyer 1953, 10-12). What Sambasiva Iyer did compose was limited to cittasvara-precomposed rhythmic arrangements of svara (notes) which are added to the anupallavi (second section) and caranam (final section) of compositions-and notes (a genre of wordless song influenced by British band music), neither of which involve text. ${ }^{9}$

According to his students, Sambasiva Iyer carefully refined compositions before performing them. This process often included developing new sangati (melodic variations on a line of text) or modifying existing sangati to correspond to his aesthetic sense of balance. Although composing or altering sangati involved setting a text to new melodies, it did not entail creating new texts. His older brother, however, Subbarama Iyer, not only composed new sangati but also composed entire compositions to such classic texts as the têvaram. ${ }^{10}$ Neither brother created new texts.

Sambasiva Iyer's unwillingness to introduce new compositions with new texts into the repertoire of South Indian classical music (known in India as karnataka sangita) suggests a reverence for the canon of compositions created and passed down by the masters before him, a sentiment shared by conservative musicians. A similar reverence surrounded his approach to teaching music, which proceeded nonverbally. Iyer gave little credence to intellectual debates over proper musical practice, for he believed that "sangita is [found] neither in speaking, nor in writing, nor in debate. Sarigita is an art of sound, [and] therefore should not be handled in any other manner" (Sambasiva Iyer 1953, 15).

Sambasiva Iyer further expressed his religious devotion and respect for art through a staid and emotionless appearance in performance (in public or in private), through an unwillingness to limit or change his playing to suit an audience (Subramanian 1986, 22), and through his consistent use of $\bar{i} n \bar{a}$ in $p \bar{u} j \bar{a} .{ }^{11}$ In an interesting parallel to other strictures concerning pollution in Brahmin practices, Iyer believed that styles and forms should retain their own individuality and purity and not be mixed (Sambasiva Iyer 1953, 18).

\section{Disciples of the Karaikkudi Brothers}

The late Karaikkudi Lakshmi Ammal, my vin̄a teacher, was the third of Subbarama Iyer's five daughters. She learned vocal music from 
her father but had to teach herself the vinna as women in her family did not play the instrument and her father refused to teach her. (This constraint was gradually lifted as public attitudes began to change in the late 1920s.) By the time her father consented to teach his daughters vinna $\bar{a}$, Lakshmi Ammal had already married and moved out of the house. Her two youngest sisters, Sankari Ammal and Meenakshi Ammal, were the only women to learn from Subbarama Iyer.

In 1939, three years after the death of her father, Lakshmi Ammal gave birth to a daughter, Raajeswari. Raajeswari showed talent from an early age, easily reproducing the lessons her mother was teaching to other students. As a child in a musical household she was not subjected to the kind of rigor normally imposed on a student undertaking gurukulaväsa, a system of training in which the disciple lives with the master. For example, she did not start out by learning exercises such as sarali varasa but by learning short songs. And although her mother was teaching viña to many students outside the family, she did not make a special effort to teach Raajeswari. ${ }^{12}$ Smt. Raajeswari has fond memories of these days, in which she would learn folk songs and dances and playfully compose pallavi, one of which, for example, was a song to attract the attention of the eggplant vendor (Padmanabhan 1988).

Meanwhile, after the death of his brother in 1936, Sambasiva Iyer

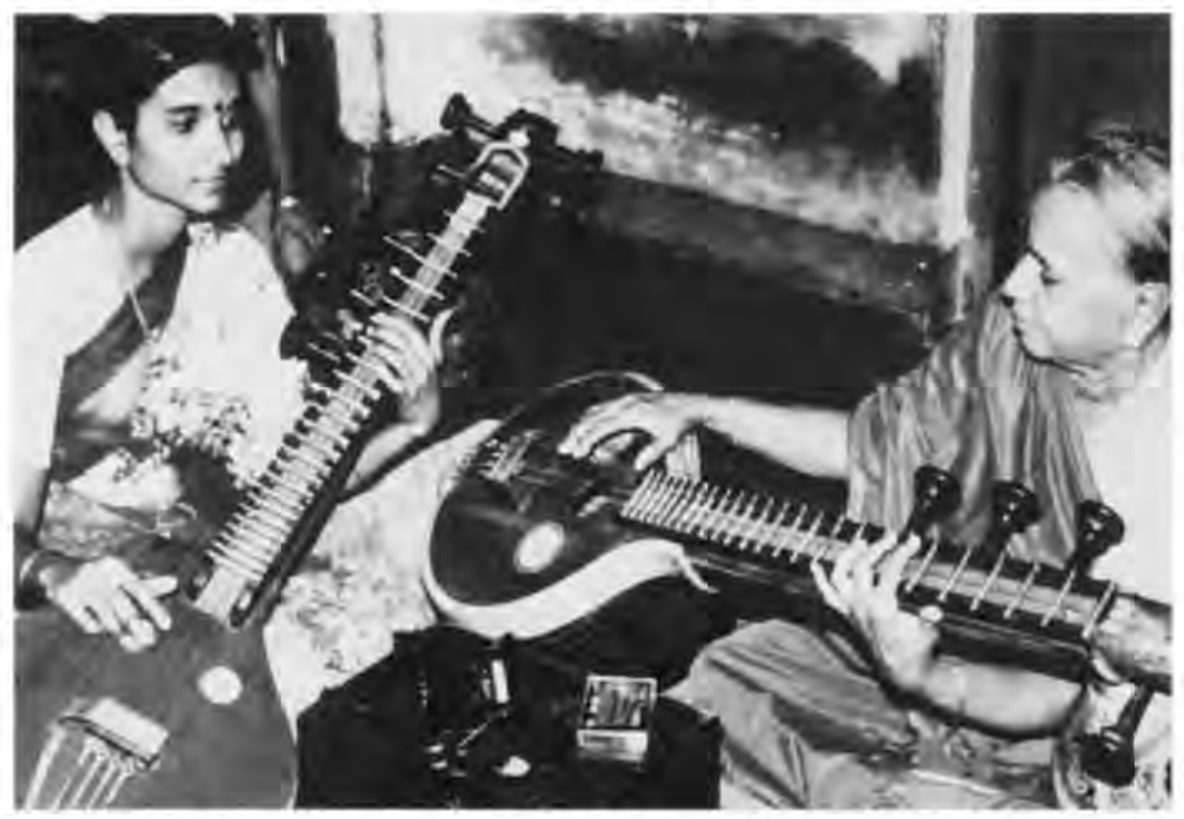

Figure 3. Subbarama Iyer's third daughter, Smt. Lakshmi Ammal (right), taught herself to play the viña; she is shown here with her niece, Smt. Sugantha Sridharan. (Photo courtesy of John Nelson.) 
retreated from public view. During this period a friend and neighbor used to visit regularly, bringing along her small child Ranganayaki. Noticing the talent she possessed even at the age of three, her aunt begged Sambasiva Iyer to train the young Ranganayaki on the vinna. After refusing repeated requests he finally agreed and initiated her in 1936 on vijayädasa$m \bar{\imath}$ day, a Hindu holiday auspicious for new undertakings.

From the very beginning, as Smt. Ranganayaki recalls it, she was forced to play on a full-sized vinna and was subjected to a rigorous routine: from four in the morning she would practice for several hours; only then would she be permitted to have some coffee, take her bath, and eat. The rest of the day would continue in the same manner: she would play for several hours at a time and stop only to eat, perform pujā, or do chores. Her teacher insisted that she practice each set of basic lessons (sarali varasa, janta varasa, alaikäram, and so forth) over and over again for one year each before proceeding to the next set. If she made an error she was severely reprimanded and forced to begin again. Smt. Ranganayaki said that she detested playing the instrument at this time but noted that she had no choice. She recalls beginning to enjoy playing the viña only after she was well into her teens, married, and playing professionally (Rajagopalan 1988).

In 1941 Sambasiva Iyer appeared in concert for the first time since his brother's death, and Smt. Ranganayaki accompanied him. Kalki published an eloquent description of this long awaited concert which told of the public's surprise on seeing Smt. Ranganayaki, the "little girl with the big vina." Just as Sethuraman, twenty-two years later, compared the brothers to Śiva and Śakti, Kalki compared the power ('́akti) obtained by steadfast practice on the viña to that obtained by risi who, through sometimes harsh acts of asceticism, expressed their devotion to the divine. Just as these ascetics could give other people their power, so could the brothers share their sakti with others. Kalki mused that Smt. Ranganayaki was able to attain an unusual degree of skill at the young age of ten because the brothers shared with her the sakti they obtained through incessant practice (Kalki 1941). After astounding the audience in that performance, Ranganayaki appeared with her teacher in all of his performances.

In 1944, Sambasiva Iyer regularly visited his niece Lakshmi Ammal in the city of Madurai and watched her daughter Raajeswari pick up the family musical tradition. Eventually he requested that she be sent to him for training. Smt. Raajeswari describes her parents as feeling honored and reluctant; but, since out of respect for Iyer they could not deny his request, they complied. Smt. Raajeswari learned under significantly different conditions than did Smt. Ranganayaki. By the time she began training, Smt. Raajeswari recalls, Iyer's grief over losing his brother had subsided enough to allow him to resume performing and he had aban- 
doned his habit of scolding his pupils severely. Not only were conditions different, but Smt. Raajeswari held an attitude toward music that was different from Smt. Ranganayaki's. For Smt. Raajeswari, music was something to be played with, something for personal expression and fun. She did not regard her uncle with fear and awe as did Smt. Ranganayaki, for her relationship with him was one of family love. As a result, it is not surprising to learn that when Smt. Raajeswari began lessons with Sambasiva Iyer she tended to follow his example less rigidly than had Smt. Ranganayaki. Smt. Raajeswari too began with basic exercises; but she was, in effect, polishing lessons that her mother had introduced informally. When Smt. Raajeswari began learning compositions she would add her own creative touches. She claims Sambasiva Iyer would respond approvingly, "śábăs"s" ("bravo"). Generally pupils are expected to follow their teachers precisely; only in later stages of playing do they develop their own individuality. Students attempting to play their own way from the beginning are considered disrespectful and usually punished.

In the last years of his life, Sambasiva Iyer would perform with his two senior disciples, Smt. Ranganayaki and Smt. Raajeswari, and occasionally with some of his other students. In 1948, ten years before his death, he was persuaded to come to Madras, where he acted as president of the Perumbur Sangeetha Sabha (a music school) and, later, as principal of Kalakshetra (a school of classical Indian music and dance). In many ways, his attitudes conflicted with those of the institutions: he advocated slow thorough training, but music schools needed shortcuts; he shunned verbal discussions of music, but scholars insisted on developing standards of "correct" practice; he focused on the ritual and spiritual function of music, but institutions stressed the academic and professional functions. Given these conflicts, it is a wonder that Iyer ever agreed to come to Madras after having refused repeated invitations from various musical institutions. Accounts say he accepted because of "divine inspiration" (Sethuraman 1952). The musical institutions were more interested in the symbolic nature of his presence than his actual participation in the teaching process-indeed, how could a student spend entire days at school? Who could afford ten years of schooling?

Mr. Rajagopalan, Smt. Ranganayaki's husband, narrates the chain of events following Iyer's death: "[When] Mr. Karaikkudi Iyer died in 1958, Mr. Sankara Menon, director, Kalakshetra, wrote to Smt. Ranganayaki Rajagopalan offering the post of vinna teacher to Ranganayaki since Ranganayaki was teaching in Kalakshetra while Sambasiva Iyer was very ill. Ranganayaki declined the job on account of the distance and some family problems" (pers. com. 1990). After Smt. Ranganayaki declined, Smt. Raajeswari was offered the post at Kalakshetra and has taught there for the past thirty-two years. Within the Karaikkudi family, 


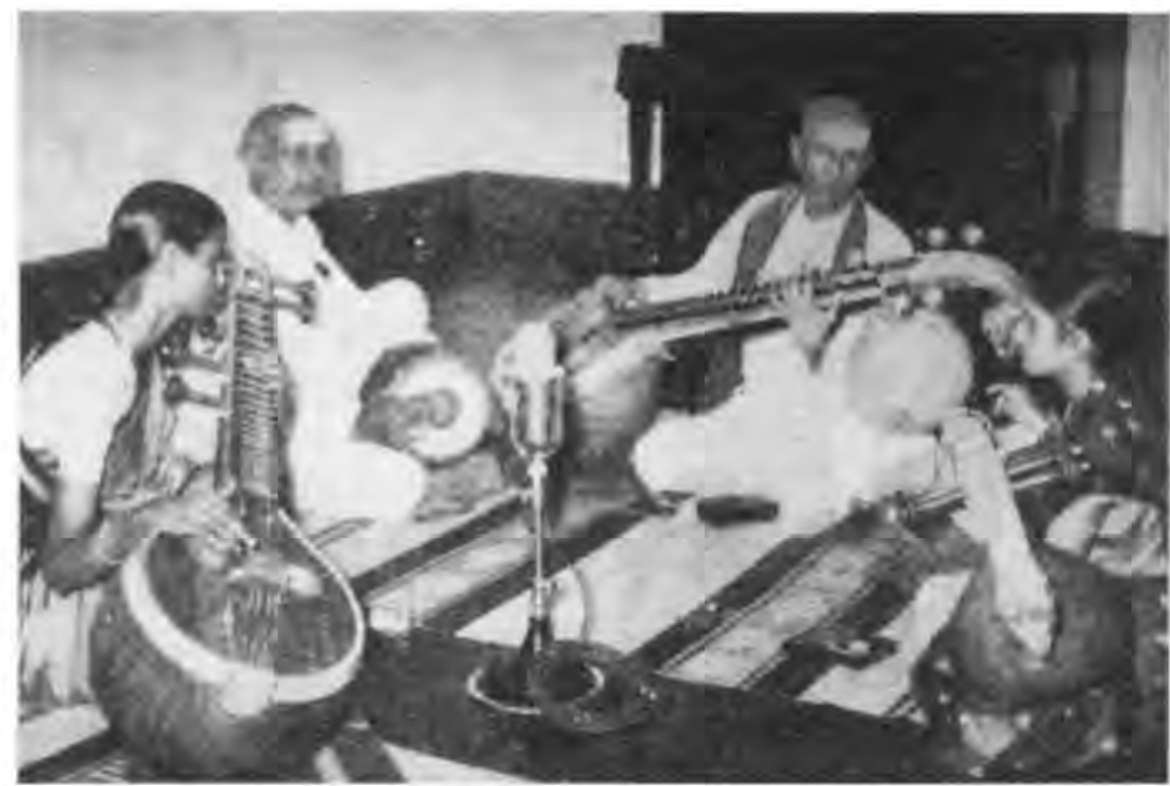

Figure 4. Karaikkudi Sri Sambasiva Iyer, Smt. Raajeswari Padmanabhan, Smt. Ranganayaki Rajogopalan, and Karaikkudi Muttu Iyer (clockwise from top right) are pictured at a recording session for Sangeet Sammeln in the late 1950s. (Photo: Richard Kent Wolf.)

Smt. Raajeswari's acceptance of the post at Kalakshetra is seen as evidence that the legitimate inheritor of the family tradition is Raajeswari, the grandniece of Sambasiva Iyer, and not the more experienced Smt. Ranganayaki. According to Smt. Raajeswari's father, who may have been unaware of Sankara Menon's previous offer to Smt. Ranganayaki, the founder of Kalakshetra insisted that Smt. Raajeswari rather than Smt. Ranganayaki be offered the post of vin̄a teacher (Narayana Iyer, pers. com. 1988).

Kalakshetra's founder, Rukmini Devi, was one of the first Brahmins to adopt the art of bhäratanatyam dance, formerly associated with the temple dancing of lower-caste women (dêvādāsī). She is credited with raising the status of dancing from a "vulgar" to a refined art form. ${ }^{13}$ Although part of an educated and elite class, she lacked the artistic legitimacy that membership in a family of dancers would seem to provide. If Rukmini Devi wished to hire Smt. Raajeswari because of her blood relationship to Sambasiva Iyer, as Narayana Iyer claims, Rukmini Devi may be seen to have compensated for the absence of a family of dancers in Kalakshetra by ensuring such dynastic legitimacy was represented in the field of music. Dr. K. S. Subramanian, Raajeswari's brother and adoptive son of Sambasiva Iyer, adds that he was also asked to forgo his higher studies and remain at Kalakshetra as a teacher-because he was a mem- 
ber of the family-even though Subramanian underwent intensive training with Sambasiva Iyer for only one year. ${ }^{14}$ The symbolic place of a musical family at Kalakshetra is highlighted by the fact that, as Subramanian puts it, "it is more of a dance-Kshetra than a kala [fine arts] Kshetra" (Subramanian, pers. com. 1990).

\section{Institutions and Change}

Smt. Raajeswari Padmanabhan has now been teaching at Kalakshetra for over thirty years. In that time she has developed the musical knowledge imparted to her by her guru Sambasiva Iyer and has taken her own stances on issues of teaching, performance, scholarship, composition, and professionalism. On the one hand, she has had to conform to Kalakshetra's standards for performance and instruction; on the other, she has had to deal directly with music lovers by giving public concerts and private lessons while at the same time raising a family.

Some practices encouraged by Kalakshetra seem to conflict with the practices of Sambasiva Iyer, but not necessarily with Raajeswari's own practices or those of her mother. Such practices include composing new songs (at the request of Kalakshetra's founder, Rukmini Devi), teaching students who had previously learned other styles, teaching students in short periods of time and in time slots determined by the school, and using teaching materials such as exercises, compositions, and genres which are specified in the school curriculum.

Unlike Sambasiva Iyer who remained rather indifferent to the wishes of the audience, Smt. Raajeswari maintains a sensitive rapport with the audience both through her body language (smiles and other subtle gestures) and through her choice and rendition of repertoire. She has "developed" (her own word) some of the repertoire of her guru-repertoire now seen as old-fashioned-by interspersing fast scalar and rhythmic sangati and altering the overall rhythmic flow of certain compositions. ${ }^{15}$

In comparison with gurukulavasa in the Karaikkudi style (and in other conservative styles), music schools promote differences not only in specific practices but also in general attitudes. While the traditional method of teaching in India discourages students from asking questions and from listening to and learning from other people, music institutions foster outward-looking attitudes by representing a variety of styles and hosting students who wish to learn popular versions of compositions. These attitudes tend to induce a certain stylistic homogeneity due to the fact that students learn from many teachers at music schools. These teachers constantly interact with one another, are subjected to unified standards of teaching, and compete to perform in the same arenas. 
Smt. Raajeswari's attitudes are outward-looking and have brought about some degree of stylistic homogeneity even though, by her own standards, the Karaikkudi style remains unique. In order to introduce a certain "sweetness" she finds in North Indian music, for example, Smt. Raajeswari has altered the "choppy" quality she perceives in the Karaikkudi technique by allowing the strings to resonate longer between plucks and by deemphasizing aluttam (emphasis or pressure on the strings characteristic of Smt. Ranganayaki's and Sambasiva Iyer's playing). ${ }^{16}$ Although she says the music of South India is different from that of North India, and comprises a different system, she justifies her changes by saying that one was derived from the other and implying that her innovation merely returns musical aspects that have been lost over centuries of musical evolution (Padmanabhan 1988).

Smt. Raajeswari has also introduced structural changes into the rendering of improvisational forms. These changes include, for example, softening the articulation between rāga aläpana (melodic elaboration in a free rhythm) and tänam-which, to her, lends a sense of "continuity" to her playing that she finds absent in the playing of her guru Sambasiva Iyer. Not only does she soften the articulation between the two forms (between the end of àlapana and the beginning of tānam) but she also intersperses passages of tānam in climactic portions of rāga ālāpana. Portions of the tānam section are traditionally articulated by phrases of ālāpana, but the reverse was not the case in the Karaikkudi style. Unlike Sambasiva Iyer, she ends her expositions of tanam with a cadence repeated in three registers (Padmanabhan 1988; Rajagopalan 1988).

Smt. Ranganayaki Rajagopalan, on the other hand, has held rigidly to many of her guru's attitudes and practices. Sambasiva Iyer restricted himself to composing new sangati, cittasvara, and notes-none of which involved the use of newly composed or newly appropriated texts. Although Smt. Ranganayaki feels capable of composing, she has extended the restriction practiced by her guru by composing nothing herself other than sangati, which she considers aspects of rendition rather than of composition (Rajagopalan 1988). She has continued to play with a "Karaikkudi" kind of grip (aluttam) on the vinna and with an intensity of plucking that makes for loud, concise, and discrete musical gestures. Whereas this aspect of playing style may originally have been a way of reaching large audiences before the advent of the microphone, for her it is now an independent aesthetic feature of the style. But as mentioned above, Smt. Raajeswari finds this aspect of style obsolete.

Whereas Smt. Raajeswari has developed most of the repertoire taught by her guru, Smt. Ranganayaki has either continued to play compositions as she learned them or (if they are out of vogue) has stopped playing them publicly. Both performers have added new compositions to 
their repertoire. The process of learning such compositions sometimes involves the use of cassette players and the radio. ${ }^{17}$ That Smt. Ranganayaki is willing to learn compositions from a cassette recording reflects her general sentiment that compositions should take a relatively fixed form (a sentiment imparted, in all probability, by her guru Sambasiva Iyer). Not all musicians in the Karaikkudi style share this sentiment, however. Lakshmi Ammal, for example, refused to let her students learn from tape recordings because she used to vary her renditions from lesson to lesson; Smt. Ranganayaki's renditions are relatively stable. ${ }^{18} \mathrm{Smt}$. Ranganayaki's attitude toward the preservation of compositions is expressed similarly toward forms of improvisation. Raga a alappana is kept distinct from tānam, and a clear gap separates the two. Her cadential patterns at the end of tānam are executed in one register only (Rajagopalan 1988).

Unlike Smt. Raajeswari, who has been associated with Kalakshetra for the last thirty years and has enjoyed wide popularity, Smt. Ranganayaki taught at the Madras Music Academy for ten years and has had little popular exposure. Indeed the academy, long known for its rigid standards and preference for vocal music, never offered Smt. Ranganayaki a chance to perform and eventually she resigned. ${ }^{19}$ As a further indication of the role musical institutions may play in the development of musical style, one may note that both the conservatism of the institution and Smt. Ranganayaki's limited exposure within it may account, in part, for the degree to which she has been able to maintain the practices and values of her guru.

\section{Style, Legitimacy, and Central Characteristics}

The fact that Smt. Raajeswari has changed aspects of the style that her guru and Smt. Ranganayaki may have felt essential should not lead one to conclude that Smt. Raajeswari is drifting away from the style. Rather, she has a different notion of what constitutes the style. To her, the key characteristic of the Karaikkudi style is "fingering." With this technical view of the essence of her tradition, the many changes she has effected in content (modifying the rendition of compositions for which the Karaikkudi brothers were famous), in structure (in such improvisational forms as aläpana and tānam), and in technique (reducing the amount of aluttam and modifying the degree of staccato achieved by the right-hand plucking technique) can be understood as remaining true to the style.

For Smt. Ranganayaki, maintaining the style means that the repertoire and technique must remain intact; stage presence must be austere and staid; and one must not draw attention to oneself by composing, playing in a flashy manner, or borrowing gestures from other popular vinn̄a players. These attitudes may have proved a hindrance to building a 
career in an institutional setting; and the fact that Smt. Ranganayaki spent only ten years at the Music Academy may to some extent account for the degree to which she was able to maintain them.

For both Smt. Ranganayaki and Smt. Raajeswari, and for styles in South India in general, the rise in institutional music training and the decline in gurukula training has gradually shifted the characterization of style from a holistic one that considers values, performance contexts, and teaching process, as well as repertoire and technique, to a technical one that is centered on aspects of execution. Thus, for example, both artists express surprisingly little concern with the loss of vina $\bar{a}$ music in religious functions.

Other contributions to conservatism and change arose from the upbringing of the two artists. The strict manner in which Smt. Ranganayaki was raised and trained undoubtedly played a role in shaping her personality and limiting her outlets for innovation. Smt. Raajeswari's upbringing always encouraged innovation; as she grew older, the innovations expanded to matters of form and performance practice.

Smt. Raajeswari, however, is traditionally bound to the style in a way that Smt. Ranganayaki can never be, for she possesses a family legacy of eight generations. This legacy is an implicit bond with the past that permits a freedom for innovation that might not be tolerated if exercised by someone outside the family. ${ }^{20}$ But membership in a musical family also entails certain responsibilities. First, a musician's playing must have an aural component which convincingly suggests the playing of others in the style. The degree of leeway within the style is not infinite despite the obvious difficulties of attempting to draw rigid stylistic boundaries-family musicians cannot do "just anything." Second, audiences expect a great deal of technical proficiency and imagination in the playing of such a musician. Hereditary musicians may be offered more work than other musicians, but they are forever being compared with other famous musicians in their family. Smt. Ranganayaki must also assume these responsibilities - not as a family member but as a disciple of Sambasiva Iyer. In fact, Smt. Ranganayaki must perform very much like Sambasiva Iyer to maintain her legitimacy in the eyes of music connoisseurs. Thus we find that Smt. Ranganayaki is tied to tradition by a larger number of concrete manifestations of style than Smt. Raajeswari, even though she studied with Sambasiva Iyer for twice as long.

Smt. Ranganayaki and Smt. Raajeswari continued to perform together for several years after Sambasiva Iyer died, but as the two artists matured they began to drift apart-socially and musically. Dr. K. S. Subramanian, Smt. Raajeswari's brother and adoptive son of Karaikkudi Sambasiva Iyer, recently requested that Smt. Ranganayaki and Smt. Raajeswari perform together on television. He hoped to have them play 
"Sarasinuhä," an old standard of the Karaikkudi repertoire the two women had played together on many occasions when they were children. Both artists had continued to play the composition in concerts, on the radio, and on commercial recordings. While Smt. Ranganayaki retained in her version the same structure of sangati performed by Sambasiva Iyer, differing only in such details as choice of where to bend or pluck the string with the left-hand fingers, Smt. Raajeswari had developed a stable new version which she performed regularly with her daughter Sri Vidya. ${ }^{21}$ For this reason Smt. Ranganayaki and Smt. Raajeswari were unable (or at some level unwilling) to perform "Sarasiruha $\bar{a}$ " together as they had in the 1950s and 1960s. The television program featured one performance of the kriti by Smt. Raajeswari and Sri Vidya and one performance by Smt. Ranganayaki and her daughter Jayanti.

Although they belong to the same style, one finds few characteristics common to both artists: a couple of fingering techniques, some exercises, and perhaps the rendering of a few compositions. It would be inaccurate to call these features the essential features of the style simply because both artists exhibit them, but it would be equally inaccurate to claim that one artist is less representative of the style than the other (although they may hold such attitudes about each other). The diversity of approach displayed by the two performers is true of the style as a whole. Each member has interpreted the traditional knowledge transmitted by their guru in different ways. The style, then, comprises a number of different but related strains, each consistent within itself, all revealing different aspects.

This multidimensionality complicates issues of assessing historical change. The analyst is at a loss to determine an analytic baseline for change- at least one with any historical depth-because the characteristic features of the "Karaikkudi style" remained undocumented before the Karaikkudi brothers rose to fame, and performers today interpret, if not construct, the past in accordance with their own notions of "tradition." It is apparent, however, that even the brothers themselves played differently from one another-forming a complementary pair. Now members of the Karaikkudi style, of whom Smt. Ranganayaki and Smt. Raajeswari are two prominent examples, have developed their playing in manners sometimes incompatible with those of other members with whom they have ceased to have musical contact.

Why, then, are Karaikkudi vinn $\bar{a}$ players regarded as members of "a style"? Who sees them as such? At a broad societal level, style in and of itself is valued - not only by students of the style but by concert organizers as a means of drawing larger audiences and by the listening public as a reaffirmation of a South Indian "ancient tradition." More narrowly, music connoisseurs are likely to view Smt. Ranganayaki, Smt. Raa- 
jeswari, other disciples, and family members as mere projections of their illustrious guru and forebears as a result of persisting memories and legends still circulating about the Karaikkudi brothers. The existence of a connection between the past and present is widely known and felt, even if the precise nature of this connection is contested. One kind of listener typically remarks, "Oh, Ranganayaki Rajagopalan's playing is so pure," while another insists that "Raajeswari Padmanabhan has really added something to the style." Indigenous discourse creates oppositions between continuity and change, the static and the elastic, the traditional and the modern. ${ }^{22}$ These sets of oppositions are articulated socially-in a general way, and not surprisingly-by conservative and progressive individuals respectively. The relativity implied in these attitudes about musical style does not mean that musical sound itself is not a strong diagnostic feature; rather, it indicates that the emphasis (or deemphasis) of such aural components is not a structural given.

The factors affecting public perception of Smt. Ranganayaki and Smt. Raajeswari as carriers of the Karaikkudi tradition are similar to those that affect the artists' view of their own role in their tradition-and to those that bear on tradition in general. Other descendents of the Karaikkudi brothers hesitate to criticize Smt. Raajeswari, even if they themselves espouse stylistic purity. Some members of the style outside the family, however, feel free to criticize Smt. Raajeswari for taking too many liberties with the style, while they themselves hold rigidly to the attitudes and techniques of the past. Smt. Ranganayaki and Smt. Raajeswari disapprove of one another's playing to a certain degree because they have different notions about what constitutes a proper "Karaikkudi" performance. But they refrain from openly criticizing each other because unifying factors of guru, style, caste (Iyer Brahmins), and musical universe (Madras vin̄a players) tend to promote solidarity.

\section{A Few (Tentative) Conclusions}

I have suggested the factors which may induce stylistic diversity; these include the varying conditions under which students learn, membership vs. nonmembership in a musical family, association with musical institutions, and subtle aspects of personality which may not be traceable to overt causes. Some of these factors appear to create various dispositions toward innovation. For example, a member of a musical family may have more leeway to innovate than an outsider-regardless of whether the hereditary musician decides to take advantage of this leeway. Musicians who have had extensive contact with musical institutions may express a more universalistic, outward-looking attitude toward innovation within the style than musicians unattached to such institutions. These must be 
considered very tentative conclusions, however, for many factors shape a musician's development.

Returning now to the maintenance of tradition in Karaikkudi vinn $\bar{a}$ playing, it is evident that the "tradition" being maintained is neither singular nor easily definable, for what appear to be enduring constructs for one artist sometimes turn out to be changeable for another. From the shifting perspectives I have outlined we may understand that the notion of style in South India is flexible enough to allow for interpretations which appear to contradict each other and that maintenance of style in South India need not mean adherence to a structural core, an assumption that figures in many studies concerning style. Rather, style may be maintained through individual choices and responses to individual circumstances. ${ }^{23}$

The observations and conclusions presented here may be relevant to the study of other traditions in Asia transmitted from master to disciple - especially given similar worldwide changes in educational and economic systems. Members of these traditions commonly claim some sort of connection with great personages of the past, and a group of such people is seen to form a "school" or a "style." The complex processes by which new styles are formed, old styles expanded and modified, and tradition itself reaffirmed may be revealed further in detailed case studies.

\section{NOTES}

1. This article is based on my observations as a student of Tamil and the vinna in Madurai and Madras, Tamil Nadu, South India, from August 1982 to June 1983, from December 1984 to February 1986, and a six-week visit in the winter of 1987-1988, as well as conversations with viña players in the United States. A version of this paper was presented at the Seventeenth Annual Conference on South Asia at the University of Wisconsin-Madison on November 4, 1988, and selected portions appear in my Master of Music thesis (Wolf 1989). All Tamil, Telugu, and Sanskrit words are transcribed according to the Library of Congress system, but the vowel " $r$ " (as in rssi) is transliterated "ri." I would like to thank Raga Mala Performing Arts of Canada and the Graduate College of the University of Illinois for financial support of this research.

2. Meyer Shapiro first problematized this notion of style in his 1953 paper in Anthropology Today. The conceptual history of the use of "style" as a technical term in academic discourse is beyond the scope of this paper. For further information, the reader is directed to works by Gombrich (1968), Kubler ([1962] $1976 ; 1967)$, Ackerman $(1962 ; 1978)$, and essays in Lang (1987).

3. Some scholars, however, resist such notions of cultural holism; see, for example, Gombrich (1968, 358).

4. See Alpers ([1979] 1987, 139), who begins to problematize the formation of external systems of style classification. 
5. The concerns of these anthropologists have been greatly simplified for the present discussion in order to distinguish basic differences in notions of "style." Significant examples include Ruth Benedict's Patterns of Culture (1934), A. L. Kroeber's Style and Civilizations ([1957] 1973), and chapters in Anthropology (1923). Clifford Geertz's Negara (1980) and Steven Feld's “Aesthetics as Iconicity of Style" (1988) are examples of recent, more sophisticated attempts to define cultural style by identifying recurrent themes and patterns.

6. Bourdieu's notion of habitus can be seen as a solution to a similar problem (1977). Although the complexity of Bourdieu's ideas cannot be encapsulated in a few words, he argues that people constantly internalize the structures perceived as existing in the activities, objects, and events of the external world and creatively project these structures into everything they do. These shared structures, believed to reside in the "habitus" of human psyches, are seen to be the basis of cultural coherence. Thus Bourdieu's habitus might be seen as the generating force, or at least involved in the generative process, that produces a cultural "style."

7. The vinna, or sarasvati viña, is a plucked string instrument. For information concerning its origins and development see Powers (1980), Subramanian (1985), and Wrazen (1986).

8. The Karaikkudi fingering technique entails keeping the index and middle fingers of the left hand together when playing ascending passages and separated when fingering descending passages. The manner of rendering such gamaka (integral ornaments) as pratyāhata (a way of stressing a repeated pitch in descending passages) and sphurita (stressing a repeated pitch in ascending passages) are stressed in the Karaikkudi style, as are techniques for such gamaka as the ravai. See Sambasiva Iyer's identification of these techniques in the Journal of the Music Academy of Madras $(1953,35)$ and the discussion in Subramanian (1986, 93-96).

9. "Note" is an English word adopted into South Indian musical terminology. The best-known note was made popular (and probably composed) by the late Madurai Mani Iyer. It is known, distinctively, as "English Note."

10. Subbarama Iyer's fondness for setting texts to music is consistent with his overall specialization in performance-melodic improvisation on texted musical passages (that is, niraval svara).

11. He played not while performing arcanā (the aspect of worship involving the showering of the deity with flowers and scented grain), but in the context of the general worship event. Sometimes Iyer would direct students to repeat a lesson a prescribed number of times (say, the auspicious number 108) while he lit the oil lamp and incense and recited the necessary mantra. In these situations the number of repetitions was more important than the accuracy of performance (Padmanabhan 1988).

12. Lakshmi Ammal learned from her father in this manner and taught all her children, except for her daughter Sashikala, in the same indirect way.

13. For further information on Rukmini Devi, Kalakshetra, and the renaissance of bhäratanātyam, see Sarada (1985), Janah and Chatterjee (1979), and Krishna Iyer (1971). 
14. Subramanian now understands this year of training to be the basis of his own personal style. Just as Smt. Ranganayaki's playing resembles that of Sambasiva Iyer in very concrete terms (repertoire, technique, stage presence, and so forth) and Smt. Raajeswari's playing resembles that of Iyer in fewer characteristics (fewer techniques, less repertoire, and fewer years of studying), Dr. Subramanian sees his own connection to Sambasiva Iyer at the most abstract level, at which, in some sense, the essence of Iyer's mature style has been preserved within the initial exercises-exercises Subramanian was forced to master in his yearlong gurukulavāsa.

15. Her renditions of the compositions "padavin̄" and "êlani dayarādu," for example, represent such developments (see Wolf 1988).

16. Other performers in the Karaikkudi style have also changed this aspect of plucking technique-most notably Raajeswari's brothers (Subramanian 1986, 182).

17. For discussion of the implications of such practices see Wolf (1989, 212-214).

18. There were other reasons for her unwillingness to allow students to learn from recordings. Beginning students might develop habits of playing incorrectly by relying solely on their ears. An important part of learning involves imitating posture, hand position, and right and left hand fingering. In terms of these aspects Smt. Ranganayaki would also hesitate to let her beginning students learn from tape recordings.

19. Smt. Ranganayaki has since gone on a concert tour in Europe, and I am told she has been performing widely at the Music Academy and elsewhere (Butler 1990, pers. com.).

20. According to Peter Row (1978), who examined gharāna in North India, students in musical families are taught differently from those outside the family. Although, generally speaking, my research does not contradict this observation, I have found that a student's attitude, age, status, and even where a student lives may play roles comparable to membership in a musical family in determining how a student will be taught.

21. This version can be heard on the cassette Veena Classical by Rajeswari Padmanaban (AVM MEI-SR 1076).

22. Although as Singer ([1972] 1980) and Rudolph and Rudolph ([1967] 1984) have shown, the "modern" India is in its own way "traditional," people themselves still reminisce about "the good old days," debate whether India has benefited from increased industrialization and contact with the West, and either praise or condemn a musician's use of musical "gimmicks." Oppositions of the sort listed, I claim, are maintained through these disagreements.

23. Kippen, in his recent study of a Lucknow tabla gharāna (1988), reaches similar conclusions concerning the centrality of individual strategies and decision making in the formation of musical style.

\section{REFERENCES}

Ackerman, James S. 1962.

"A Theory of Style." Journal of Aesthetics and Art Criticism 20:227-237. 
1978.

“On Rereading 'Style'." Social Research 45:153-163.

Alpers, Svetlana. [1979] 1987.

"Style Is What You Make It." In The Concept of Style, edited by Berel Lang. Ithaca: Cornell University Press.

Balaji, Nithya. 1988-1989.

"Rajeswari Padmanabhan: Looking Back and Ahead." Sruti 51/52 (Dec.-Jan.):35-36.

Balasubramanyam, G. N. 1955.

"Karnatak Music." In Radio Sangeet Sammelan, November 10-15. Delhi: Publications Division, Ministry of Information and Broadcasting, Government of India.

Benedict, Ruth. 1934.

Patterns of Culture. New York: Mentor Books.

Bhuvarahan, N. R. 1978.

"Veena Sambasiva Aiyar." Shanmukha (Bombay) 4:11-15. 1988.

"Vina Sambasiva Aiyar." In Birth Centenary of Sangita Kalanidhi Karaikudi Sambasiva Iyer. Madras: India International Rural Cultural Center.

Boas, Franz. [1927] 1955.

Primitive Art. New York: Dover.

Bourdieu, Pierre. 1977.

Outline of a Theory of Practice. Translated by Richard Nice. Cambridge: Cambridge University Press.

B.S.S. Music School. 1984.

“ "Veena Visarada' Smt. Ranganayaki Rajagopalan." Pamphlet released in connection with unveiling a portrait of Sambasiva Iyer and conferring the title of "Veena Visaradha" on Ranganayaki Rajagopalan on 26 January 1984, at Srinivasa Sastri Hall in Madras.

Deshpande, Vamanrao. 1973.

Indian Musical Traditions: An Aesthetic Study of the Gharanas in Hindustani Music. Translated by S. H. Deshpande. Bombay: Popular Prakashan.

Ellarvi [L. R. Venkataramayyar]. [1965] 1967.

"Kāraikkuṭi Cakōtararkạ̣." In Kalai Maṇikal. Madras: Amuta Nilaiyam Limițeț.

Feld, Steven. 1988.

"Aesthetics as Iconicity of Style, or 'Lift Up over Sounding': Getting into the Kaluli Groove." Yearbook for Traditional Music 20:74-113.

Geertz, Clifford. 1980.

Negara: The Theatre State in Nineteenth-Century Bali. Princeton: Princeton University Press.

Gerbrands, Adrian. 1969.

"Style in Non-Western Art." In Tradition and Creativity in Tribal Art, edited by Daniel P. Biebuyck. Berkeley: University of California Press.

Gomati Sankara Ayyar, V. S. [V. S. Kōmaticañkara Aiyar]. 1970.

"Pallavi Cuppaiyāpākavatar, Vīnai Cupparāma Aiyar, Vīnai Cāmpaciva Aiyar." In Icaikkalai Vallunakal. Annamalai Nagar: Civakāmi Accakam. 
Gombrich, E. H. 1968.

"Style." In International Encyclopedia of the Social Sciences, edited by David L. Sills. Vol. 15. New York: Macmillan.

Goodman, Nelson. 1975.

“The Status of Style." Critical Inquiry 1(4):799-811.

Hibbert, Lloyd. 1958.

"A Note on Musical Styles." Musical Review 19:201-210.

India International Rural Cultural Center. 1988.

Birth Centenary of Sangita Kalanidhi Karaikudi Sambasiva Iyer. Pamphlet released in connection with a celebration of Sambasiva Iyer's birth centenary on March 26, 1988, at the Music Academy of Madras.

Janah, Sunil (photographer), and Chatterjee, Ashoke (writer). 1979.

Dances of the Golden Hall. New Delhi: Indian Council for Cultural Relations.

Journal of the Music Academy of Madras

1953 24:9-21, 33-35.

$1957 \quad 27: 37-38$.

Kalki [Karnatakam]. 1941.

"Āṭal Pāṭal-Apūrva Kaccēri." Ananda Vikatan, September 14. Photocopy of typewritten transcript obtained from Smt. Karaikkudi Ranganayaki Rajagopalan.

Kersenboom-Story, Saskia C. 1987.

Nityasumangali: Devadasi Tradition in South India. Delhi: Motilal Banarsidass.

Kippen, James. 1988.

The Tabla of Lucknow: A Cultural Analysis of a Musical Tradition. Cambridge: Cambridge University Press.

Krishna Iyer, E. 1971.

"Bharata Natya and Its Future." Journal of the Indian Musicological Society $1: 41-55$.

Kroeber, Alfred L. 1923.

Anthropology: Race, Language, Culture, Prehistory. New York: Harcourt Brace Jovanovich.

[1957] 1973.

Style and Civilizations. Reprint. Westport: Greenwood Press.

Kubler, George. [1962] 1976.

The Shape of Time. New Haven: Yale University Press. 1967.

"Style and the Representation of Historical Time." Interdisciplinary Perspectives of Time. Annals of the New York Academy of Sciences 138 (art. 2):849-855.

Lang, Berel, ed. 1987.

The Concept of Style. Revised and expanded edition. Ithaca: Cornell University Press.

Mahalingam, T. R. 1985.

“The Carnatic Bani." Sruti 19 (October):37-39. 
Meenakshi Ammal, Karaikkudi. 1988.

Interview with the author. Periyakulam, Tamil Nadu, Jan. 10.

Meyer, Leonard B. [1979] 1987.

"Toward a Theory of Style." In The Concept of Style, edited by Berel Lang. Ithaca: Cornell University Press.

1983.

"Innovation, Choice and the History of Music." Critical Inquiry 9(3): 517-544.

Monier-Williams, Sir Monier, Leumann, E., Cappeller, C., and others. [1899] 1979.

A Sanskrit-English Dictionary: Etymologically and Philologically Arranged with Special Reference to Cognate Indo-European Languages. New ed. Oxford: Clarendon Press.

Murphy, J. Middleton. [1922] 1960.

The Problem of Style. London: Oxford University Press.

Narayan, Radhika Raj. 1984.

"Contemporary Styles of Veena Playing: A Listeners' Guide." Sruti (April):17-19.

Narayana Iyengar, Devakkottai. 1988.

"Karaikkudi Sambasiva Iyer." In Birth Centenary of Sangita Kalanidhi Karaikudi Sambasiva Iyer. Madras: India International Rural Cultural Center.

Narayana Iyer, D. K. 1986a.

"Anpumikka Unikal Ammāvin Vālkkai." Photocopy. 1986b.

"Vāiṇika Paramparai." Photocopy.

Needham, Rodney. 1975.

"Polythetic Classification: Convergence and Consequences." Man, n.s., 10:349-369.

Neuman, Daniel. 1980.

The Life of Music in North India: The Organization of an Artistic Tradition. Detroit: Wayne State University Press.

Olbrecht, Frans M. 1941.

“Centre pour l'étude de l'Art Africain à l'Université de Gand." Institut Royal Colonial Belge: Bulletin des Séances 12(2):257-259.

Orr, P. 1988-1989.

"Training Under Sambasiva Iyer: His Way or Not at All." Sruti 51/52 (Dec.-Jan.):32.

Padmanabhan, Raajeswari. 1970s.

Interview by David Reck. Tape recording. 1988.

Interview with the author. Mandavalli, Madras, Jan. 8.

Powers, Harold S. 1980.

"India II, 6: Instruments." The New Grove Dictionary of Music and Musicians. Vol. 9. London: Macmillan.

Rajagopalan, Ranganayaki. 1988.

Interview with the author. West Mambalam, Madras, Jan. 6. 
Rangaramanuja Ayyangar, R. 1972.

History of South Indian (Carnatic) Music. Madras: R. Rangaramanuja Ayyangar, "Sabarmati."

Reck, David B. 1983.

"A Musician's Tool-Kit: A Study of Five Performances by Thirugokarnam Ramachandra Iyer." Ph.D. dissertation, Wesleyan University.

Row, Peter. 1978.

"The Role of the Non-Khandani Musician in the Shaping of Musical

Change in North India." Paper delivered at the Tenth International

Congress of Anthropological and Ethnological Sciences, New Delhi.

Rudolph, Lloyd I., and Rudolph, Susanne Hoeber. [1967] 1984.

The Modernity of Tradition. Reprint. Chicago: University of Chicago Press. Sambamoorthy, P. 1952.

Dictionary of South Indian Music and Musicians. Vol. 1 (A-F). Madras:

Indian Music Publishing House.

Sambasiva Iyer, Karaikkudi. 1953.

"Address." Journal of the Music Academy of Madras 24:9-21.

Sankari Ammal, Karaikkudi. 1987.

Interview with the author. Kumbakkonam, Tamil Nadu, Dec. 26.

Sarada, S. 1985.

Kalakshetra-Rukmini Devi: Reminiscences. Madras: Kala Mandir Trust.

Sethuraman, S. [Es. Ceturāmañ]. 1952.

"Vainịika Mahā Vitv̄ān Pirammaśrī Kāraikkuṭi Sāmpaciva Ayyar Avarkal." In Silver Jubilee Conference Souvenir of the Music Academy. Madras: Music Academy.

Shapiro, Meyer. 1953.

"Style." In Anthropology Today, edited by Alfred L. Kroeber. Chicago: University of Chicago Press.

Singer, Milton. [1972] 1980.

When a Great Tradition Modernizes: An Anthropological Approach to Indian Civilization. Reprint. Chicago: University of Chicago Press.

Srinivasan, Pia. 1980

"Notes to Musik für vina südindien." Museum Collection Berlin (West) M C 8 [ISBN 3-12-17596 0-4].

Srinivasan, T. R. 1988-1989.

"Ranganayaki Rajagopalan: Holding a Mirror to the Master." Sruti 51/ 52 (Dec.-Jan.):33-35.

Srinivasan, T. R., and Jayaraman, P. C. 1988-1989.

"The Karaikkudi Veena Brothers and Ten Generations of the Tanjavur

Tradition." Sruti 51/52 (Dec.-Jan.):19-29.

Sruti. 1988-1989a.

“A Reluctant Recipient of Awards." 51/52 (Dec.-Jan.):31.

1988-1989b.

"Between the Frets." 51/52 (Dec.-Jan.):38.

1988-1989c.

"Features of the Karaikkudi Bani." 51/52 (Dec.-Jan.):30. 
1988-1989d.

"From the Fretwork of Two to a Network of Many." 51/52 (Dec.Jan.):33.

$1988-1989 \mathrm{e}$

"Karaikkudi Subramanian: Reflections in a Pool of Memories." 51/52 (Dec.-Jan.):37.

Subramanian, K. S. 1977.

"The Study of Vina Style: An Introduction." M.A. thesis, Wesleyan University.

1985.

"An Introduction to the Vina." Asian Music 16(2):7-82. 1986.

"South Indian Vina Tradition and Individual Style." Ph.D. dissertation, Wesleyan University.

Truscott, Harold. 1958.

"Style in Music." Musical Review 19:211-221.

University of Madras. 1982.

Tamil Lexicon. 6 vols. Madras: University of Madras.

Wade, Bonnie. 1984a.

Khyäl: Creativity Within North India's Classical Music Tradition. Cambridge: Cambridge University Press.

1984b.

"Performance Practice in Indian Classical Music." In Performance Practice: Ethnomusicological Perspectives, edited by Gerard Béhague. Contributions in Intercultural and Comparative Studies, no. 12. Westport, Conn.: Greenwood Press.

Walton, Kendall L. [1979] 1987.

"Products and Processes of Art." In The Concept of Style, edited by Berel Lang. Ithaca: Cornell University Press.

Wolf, Richard Kent. 1988.

"Innovation, Interpretation, and the Maintenance of Tradition in the Karaikkudi Style of Vin̄ā Playing." M.A. thesis, University of Illinois, Urbana-Champaign.

Wrazen, Louise. 1986.

"The Early History of the Viña and the Bin in South and Southeast Asia." Asian Music 18(1):35-55. 